\title{
PENANGGULANGAN KEJAHATAN BEGAL DI POLRES BANYUMAS (Dalam Perspektif Kriminologi dan Viktimologi) ${ }^{1}$
}

\author{
Rani Hendriana, Dessi Perdani Yuris Puspita Sari, Nurani Ajeng Tri Utami \\ Fakultas Hukum Universitas Jenderal Soedirman \\ E-mail: rani capu@yahoo.com
}

\begin{abstract}
Begal, a criminal action in Banyumas committed by offenders with violent and new operandi mode create unrest in society. Critical problem lies in the lack of a comprehensive approach in the science of criminology and victimology approach to find the root of the cause and countermeasures consistently correlated with the cause. This study used a qualitative sociologic juridical approach. The focus of the study are the factors that influence the occurrence of crime robber, and mitigation in Banyumas Police, which is done by using the approach of criminology, victimology and police functions. Factors that influence the occurrence of crime robber in Banyumas Police in criminology perspective is the economic factor, social environmental offender, the crime scene as possible, the impersonation of evil robber in other regions (including the role of the media), and the persistence of the fence. As in the perspective of victimology is a behavioral factor victim, victim's biological and psychological weaknesses, and situation. Begal crime prevention that has been done in Banyumas Police comprehensive enough that prevention is pre-emptive, preventive and repersif. However, there are still some obstacles in its implementation so that the expected duties and functions of the police in tackling crime needs to be improved.
\end{abstract}

Keywords: Prevention of crime, crime robber, victimology, crimonology.

\begin{abstract}
Abstrak
Maraknya kejahatan begal di wilayah Banyumas dilakukan oleh pelaku kejahatan dengan sadis dan modus operansi baru tidak sedikit menimbulkan keresahan di masyarakat. Permasalahan krusial terletak pada kurangnya dilakukan pendekatan ilmu secara komprehensif melalui pendekatan kriminologi dan viktimologi dalam mencari akar penyebabnya dan penanggulangan secara konsisten yang berkorelasi dengan faktor penyebabnya. Penelitian ini menggunakan pendekatan yuridis sosiologis secara kualitatif. Fokus pengkajian mengenai faktor-faktor yang mempengaruhi terjadinya kejahatan begal, serta penanggulangannya di Polres Banyumas, yang dilakukan dengan menggunakan pendekatan kriminologi, viktimologi dan fungsi Polri. Faktor-faktor yang mempengaruhi terjadinya kejahatan begal di Polres Banyumas dalam perspektif kriminologi adalah fakor ekonomi, lingkungan sosial pelaku, tempat kejadian perkara yang memungkinkan, peniruan kejahatan begal di wilayah lain (termasuk peran media), dan masih adanya penadah. Adapun dalam perspektif viktimologi adalah faktor perilaku korban, kelemahan biologis dan psikologis korban, dan situasi. Penanggulangan kejahatan begal yang telah dilakukan di Polres Banyumas cukup komprehensif yakni penanggulangan secara preemtif, preventif dan repersif. Namun, masih terdapat beberapa hambatan dalam pelaksanaannya sehingga diharapkan tugas dan fungsi Polri dalam menanggulangi kejahatan perlu ditingkatkan.
\end{abstract}

Kata kunci : Penanggulangan kejahatan, kejahatan begal, viktimologi, kriminologi.

\section{PENDAHULUAN}

Suatu kejahatan belum dikriminalisasi, tidak berarti perbuatan tersebut tidak dapat dikenakan sanksi. Apabila perilaku itu dinilai sebagai perilaku yang jahat dan atau merugikan anggota masyarakat, maka pelakunya pasti memperoleh 
sanksi sosial dari mayarakat.²Berkaitan dengan kejahatan begal, pada dasarnya istilah ini tidak diatur dalam hukum positif Indonesia, melainkan sebuah istilah yang digunakan masyarakat tradisional yang kemudian berkembang menjadi istilah terhadap pelaku kejahatan yang mencegat korban di jalan dan melakukan perampasan harta si korban. Adapun dalam koridor hukum positif, aksi begal biasanya dikenakan Pasal 365 Kitab Undang-Undang Hukum Pidana (KUHP) mengenai pencurian dengan kekerasan dan/atau Pasal 368 KUHP mengenai pemerasan dengan kekerasan atau ancaman kekerasan.

Suatu hal menarik, begal sebagai kejahatan konvensional justru telah menjadi sebuah fenomena kejahatan yang sampai saat ini masih meresahkan masyarakat Indonesia, termasuk di wilayah Kabupaten Banyumas. Berdasarkan data "Rekapitulasi Kasus Curas (Begal) Polres Banyumas dan Polsek Jajaran Polres Banyumas Tahun 2014 dan 2015", ${ }^{3}$ menunjukkan bahwa sepanjang tahun 2014 dan 2015 telah terjadi 10 (sepuluh) kasus kejahatan begal, di mana 3 (tiga) kasus diantaranya masih belum terungkap, 2 (dua) kasus mengakibatkan korban meninggal dunia,1 (satu) kasus korban mengalami pelecehan seksual, dan selebihnya korban mengalami lukaluka.

Kejahatan begal dengan sifatnya yang konvensional dan marak terjadi di kota lain, seharusnya lebih dapat dicegah melalui fungsi

Paul Ricardo, Upaya Penanggulangan Penyalaahgunaan Narkoba Oleh Kepolisian (Studi Kasus Satuan Narkoba Polres Metro Bekasi)", Jurnal Kriminologi Indonesia, Vol. 6 No.3 Desember 2010, Depok: Fisip UI, hlm. 435-436.

3 Data Polres Banyumas "Rekapitulasi Kasus Curas (Begal) Polres Banyumas dan Polsek Jajaran Polres Banyumas Tahun 2014 dan 2015 preemtif dan preventif Polres Banyumas. Hal ini menjadi sesuatu yang wajar, ketika dalam penanggulangan kejahatan tidak menyentuh pada akar penyebab terjadinya kejahatan begal. Proses criminal law enforcement process, saling berkaitan dengan kriminologi, karena kriminologi dapat memberikan masukan kepada hukum pidana, terutama mengapa orang melakukan kejahatan dan faktor-faktor penyebabnya serta upaya apa yang harus dilakukan agar para penegak hukum tidak melanggar hukum. ${ }^{4}$ Termasuk pula viktimologi, banyak peneliti menyarankan bahwa dalam memahami kejahatan secara lebih komprehensif, faktor kejahatan tidak hanya dapat dipahami dari sisi penjahatanya saja tetapi dapat juga dipahami dari sisi korban. ${ }^{5}$ Berdasarkan hal tersebut, pendekatan krimininologi dan viktimologi merupakan entitas yang penting dan stategis dalam mencari akar penyebab terjadinya kejahatan begal dan memberikan penanggulangan yang tepat.

\section{PEMBAHASAN}

Berdasarkan hal tersebut di atas, peneliti tertarik untuk membahas mengenai faktor-faktor apa yang mempengaruhi terjadinya kejahatan begal di Polres Banyumas dalam perspektif kriminologi dan viktimologi dan bagaimanakah penanggulangan kejahatan begal di Polres Banyumas.
4 Ediwarman, "Paradoks Penegakan Hukum Pidana Dalam Perspektif Kriminologi di Indonesia", Jurnal Kriminologi Indonesia, Vol. 8 No. 1, Mei 2012, Depok: Fisip UI, hlm. 41.

5 Yazid Efendi, 2001, Pengantar Viktimologi: Rekonsialiasi Korban dan Pelaku Kejahatan, Purwokerto: Universitas Jenderal Soedirman, hlm. 26. 


\section{MOTODE PENELITIAN}

Penelitian ini menggunakan metode dengan pendekatan yuridis sosiologis, yakni pendekatan yang mengkonstruksikan hukum sebagai refleksi kehidupan masyarakat itu sendiri yang menekankan pada pencarian-pencarian, keajegan-keajegan empirik, termasuk pula melakukan observasi terhadap tingkah laku yang benar-benar terjadi. ${ }^{6}$ Penelitian ini juga merupakan penelitian kualitatif, didasarkan pada alasan bahwa hukum dalam penelitian ini dipandang sebagai manifestasi makna-makna simbolik para pelaku sosial, ${ }^{7}$ dan apa yang ingin diperoleh serta dikaji penelitian ini adalah mengungkap dan mendapatkan makna yang mendalam dan rinci terhadap objek penelitian dan informan. ${ }^{8}$

Informan penelitian (narasumber) sebagai sampel penelitian adalah anggota Polri Polres Banyumas. Untuk memilih sampel yang representative dilakukan dengan cara Purposive Sampling, yakni salah satu strategi pengambilan sampel non-acak. ${ }^{9}$ Untuk pemilihan informan berikutnya dipilih metode Snowball Sampling. Berdasarkan metode ini, maka Informan penelitian tidak hanya anggota Polri di Polres Banyumas, melainkan juga anggota Polri di beberapa Polsek yang menangani kasus begal. Pemilihan anggota Polri sebagai sampel penelitian, dikarenakan dipandang lebih dapat memberikan informasi yang objektif berkenaan dengan faktor yang mempengaruhi terhadinya kejahatan begal dalam

Ronny Hanitijo Sumitro, 1998, Metodologi Penelitian Hukum dan Jurimerri, Jakarta: Ghalia Indonesia, hlm. 11.

Burhan Ashshofa, 2007, Metode Penelitian Hukum, Jakarta: Rineka Cipta, hlm. 33.

8 Sanapiah Faesal, 1990, Penelitian Kualitatif, Dasar-dasar dan Aplikasinya, Malang:Yayasan Asih Asah Asuh (Y A3), hlm. 21-22. perspektif kriminologi dan viktimologi dan informasi yang valid berkenaan dengan penanggulangan kejahatan begal yang telah dilakukan.

\section{PEMBAHASAN}

Faktor-faktor yang Mempengaruhi Terjadinya Kejahatan Begal di Polres Banyumas dalam Perspektif Kriminologi dan Viktimologi

Merujuk pada judul data Polres Banyumas, yakni "Rekapitulasi Kasus Curas (Begal) Polres Banyumas dan Polsek Jajaran Polres Banyumas Tahun 2014 dan 2015", terlihat bahwa bentuk kejahatan dari istilah begal adalah Curas (pencurian dengan kekerasan atau ancaman kekerasan). Hal ini diperkuat dengan pendapat anggota Polri Polres Banyumas, bahwa tidak ada definisi begal dalam perspektif hukum, melainkan tumbuh dalam culture masyarakat yang menamakan kejahatan begal sebagai kejahatan yang dilakukan dengan kekerasan atau ancaman kekerasan mengambil barang secara paksa di jalanan. Berdasarkan hal tersebut kejahatan begal merupakan pencurian dengan kekerasan atau ancaman kekerasan yang dilakukan di jalan terhadap barang yang ada di dalam kekuasaan korban. ${ }^{10}$

Berkaitan faktor yang mempengaruhi terjadinya kejahatan begal, dapat dilihat dalam perspektif kriminologi maupun viktimologi. Kriminologi adalah ilmu pengetahuan tentang kejahatan, di manasalah satu ruang lingkupnya

\footnotetext{
Soerjono Soekanto, 1982, Kesadaran Hukum dan Kepatuhan Hukum, Jakarta: Cv. Rajawali, hlm. 197.

10 Wawancara dengan KBO Reskrim Polres Banyumas, tanggal 12 Mei 2015
} 
adalah etiologi kriminal. ${ }^{11}$ Hasil penelitian menunjukkan bahwa dalam perspektif kriminologi terdapat 5 (lima) faktor yang mempengaruhi pelaku melakukan kejahatan begal.

Pertama, faktor ekonomi. W.A. Bonger sebagai kriminolog menyokong pandangan bahwa faktor ekonomi mempunyai pengaruh yang besar dalam timbulnya kejahatan, dengan menambahkan apa yang disebutnya "Subyektive Nahrungschwerung" (pengangguran) sebagai hal yang menentukan. ${ }^{12}$ Berkaitan dengan kejahatan begal, menunjukkan bahwa faktor ekonomi merupakan motivasi utama dan dominan para pelaku melakukan kejahatan begal. Adapun di sisi lain beberapa pelaku diantaranya adalah pengangguran dan residivis. Hal ini menunjukkan bahwa faktor ekomomi masih relevan sebagai faktor yang mempengaruhi terjadinya kejahatan begal.

Kedua, lingkungan sosial pelaku. M. Torttier dalam studinya menyimpulkan bahwa dalam kejahatan yang dilakukan oleh kelompok kecil (2-4 orang) merupakan pencerminan dari kepribadian dari masing-masing individu meskipun dalam keputusan bersamanya dapat berbeda apabila itu hanya dihadapi seorang diri, ini berarti bahwa kelompok dapat melakukan kejahatan, tetapi apabila hanya seorang anggota saja mungkin dapat menahan diri untuk melakukannya. ${ }^{13}$ Beberapa kejahatan begal dilakukan secara berkelompok, di mana antar pelaku memiliki peranan masing-masing dalam menjalankan aksinya. Merujuk hal tersebut, maka lingkungan

\footnotetext{
11 I. S. Susanto, 2011, Kriminologi, Yogyakarta: Genda Publishing, hlm. 1.
}

12 Ibid.,hlm. hlm. 87-88. sosial kelompok yang terbentuk, mempengaruhi perilaku secara individu dalam mengambil keputusan untuk melakukan kejahatan begal.

Kejahatan begal yang hanya dilakukan pelaku secara individual, juga tidak terlepas dari pengaruh lingkungan sosial. Sebagaimana menurut anggota Polri bahwa "Dalam kasus yang ditangani di Polsek Sokaraja faktor yang mendorong pelaku adalah dari diri si pelaku itu sendiri, masih muda sehingga keinginan untuk hidup hedonnis, foya-foya dari harta hasil kejahatan". ${ }^{14}$ Merujuk hal tersebut, jika pelaku berada pada lingkungan sosial yang steril maka lingkungan tersebut akan lebih dapat mengikat calon pelaku untuk tidak memiliki gaya hidup demikian, sehingga calon pelaku tidak melakukan kejahatan begal.

Ketiga, Tempat Kejadian Perkara (TKP) yang memungkinkan (dilakukannya kejahatan begal). Sekalipun korban memberikan kesempatan, namun apabila suatu tempat tidak memungkinkan dilakukan kejahatan, maka pelaku dapat mengurungkan niatnya untuk melakukan kejahatan. Berkaitan dengan kejahatan begal, menunjukkan bahwa beberapa kasus kejahatan begal terjadi di wilayah yang sepi dan dapat diidentifikasikan sebagai wilayah yang rawan kejahatan. Namun demikian, di sisi lain beberapa kasus kejahatan begal justru terjadi di willayah yang ramai. Hal ini menunjukkan bahwa, terjadinya kejahatan begal tidak tergantung pada sepi atau ramainya suatu tempat, melainkan lebih pada

13 Ibid, hlm. 106

14 Wawancara dengan Kanit Reskrim Polsek Sokaraja tanggal 1 Juni 2015 
tempat yang memungkinkan pelaku dapat melakukan kejahatan.

Hal di atas, berkaitan dengan teori ekologis, di mana salah satunya adalah mobilitas penduduk. Mobilitas penduduk di sini dimaksudkan hanyalah mobilitas horizontal yang pada belakangan ini dengan jelas dapat dilihat peningkatannya. Hal ini terutama karena pengaruh sarana transportasi yang semakin meningkat. ${ }^{15}$ Termasuk pula Shaw \& McKay berdasarkan hasil studinya, dia menyimpulkan bahwa angka kejahatan yang tertinggi terdapat di daerah pusat industri dan perdagangan, daerah yang paling miskin, daerah yang dihuni para emigran dan negro. ${ }^{16}$ Merujuk pada pendapat tersebut, beberapa kasus tempat terjadinya kejahatan begal di Banyumas terjadi di daerah perkotaan. Daerah perkotaan di sini identik dengan pusat perdagangan, sehingga mempengaruhi mobilitas penduduk, oleh karenanya menjadi tempat target (sasaran ) bagi pelaku begal.

Ha ini diperkuat diperkuat pula dalam kajian Viktimologi bahwa pada daerah-daerah bisnis di pinggir kota, dan pada daerah-daerah bisnis kota kecil yang terdapat harta benda berharga, tindak pidana pencurian dengan kekerasan sangat mendominasi. Termasuk pula, terdapat kecenderungan berisiko untuk menjadi korban tindak pidana kekerasan di jalan-jalan umum. Ini disebabkan pertimbangan dari pelakunya mempunyai kesempatan lebih mudah untuk melarikan diri dibandingkan dengan di jalan-jalan kecil. ${ }^{17}$

Ibid,hlm. 82.

lbid,hlm. 84-85.

Angkasa dan Iswanto, 2009, Viktimologi, Buku Ajar, FH Unsoed, Purwokerto, hlm. 35.
Keempat, peniruan kejahatan begal di wilayah lain (termasuk peran media). Salah satu teori dalam krimonogi adalah teori "Differential Association", yang berlandaskan pada proses belajar, yaitu bahwa perilaku kejahatan adalah perilaku yang dipelajari. Menurut Sutherland,apabila perilaku kejahatan dipelajari, maka yang dipelajari tersebut meliputi (a) teknik melakukan kejahatan (b) motif-motif tertentu, dorongan, alasan pembenar dan sikap. ${ }^{18}$ Adapun demikian, salah satu preposisinya menyatakan bahwa komunikasi yang bersifat nirpersonal seperti melalui bioskop, surat kabar, secara relatif, tidak mempunyai peranan yang penting dalam terjadinya perilaku kejahatan. ${ }^{19}$ Pandangan tersebut, berbanding terbalik dengan hasil penelitian, di mana salah satu penyebab adanya peniruan dikarenakan adanya peniruan kejahatan begal di wilayah lain, termasuk pula peranan media massa yang memberitakan kasus begal secara intensif. Hal ini sebagaimana menurut anggota Polri, bahwa kemungkinan terdapat pengaruh dari peran media masa yang bisa berdampak positif bagi masyarakat, tetapi terkadang negatif bagi pelaku-pelaku yakni menambah informasi soal kejahatan begal, terutama bagi pelaku-pelaku pemula. $^{20}$

Kelima, masih adanya penadah. Adanya penadah dapat menjadi salah satu faktor pendorong pelaku melakukan kejahatan begal, di mana keberadaan penadah mempermudah pelaku kejahatan begal menjual barang ilegal yakni barang hasil kejahatannya. Hal ini, tentunya tidak

18 I. S. Susanto, Op.Cit, hlm. 93-94.

19 Ibid.

20 Wawancara dengan anggota Reskrim Polsek Sumbang, tanggal 26 Mei 2015. 
berlaku bagi pelaku kejahatan begal yang tidak menggunakan perantara penadah. Penadah dalam hal ini sebagai salah satu lingkungan sosial pelaku, maka dengan memutus mata rantai antara penadah dan pelaku kejahatan begal tentunya dapat mempersempit ruang gerak pelaku.

Berkaitan faktor yang mempengaruhi terjadinya kejahatan begal, dapat pula dilihat dalam perspektif viktimologi, yakni ilmu pengetahuan tentang korban, di mana salah satu kajiannya adalah mencari sebab-sebab terjadinya viktimisasi. ${ }^{21}$ Berdasarkan hasil penelitian terdapat 3 (tiga) faktor utama yang mempengaruhi terjadinya kejahatan begal dalam perspektif Viktimologi.

Pertama, perilaku korban yakni kurang waspada (hati-hati, mencurigai), kurang dapat menempatkan diri dalam membawa barang bawaan (membawa barang yang mecolok perhatian pelaku), kebiasaan korban (pulang pagi). Mandelsohn, ${ }^{22}$ membuat suatu tipologi korban yang diklarifikasikan menjadi 6 (enam) tipe, salah satunya adalah "The victim with minor guilt and the victm due to his ignorance", yakni korban dengan kesalahan kecil dan korban yang disebabkan kelalaian. Termasuk pula salah satu tipologi dari Steven Schafer, ${ }^{23}$ adalah "precipitative victims", yakni pelaku melakukan kejahatan karena tingkah laku yang tidak hati-hati dari korban mendorong pelaku melakukan kejahatan.

Berkaitan teori di atas, maka perilaku korban di atas, pada dasarnya merupakan kualifikasi peranan korban yakni korban dengan

21 Bambang Waluyo, 2011, Viktimologi (Perlindungan Saksi dan Korban), Jakarta: Sinar Grafika, hlm. (9)

22 Angkasa dan Iswanto, Op.Cit., hlm. 28.

23 Yazid Efendi,Op.Cit, hlm. 28-29. kesalahan kecil dan korban yang disebabkan kelalaian. Korban di sini tidak menyadari bahwa dirinya membuat kesalahan kecil yakni tidak hatihati atau waspada, di mana hal tersebut justru membawa akibat yang besar.

Kedua, kelemahan biologis dan psikologis, dalam hal ini yakni usia tua lebih berisiko menjadi korban (lebih mudah dilumpuhkan),perempuan lebih berisiko menjadi korban, sumberdaya manusia yang kurang, perasaan takut terlebih dahulu atau mudah takut saat digertak pelaku. Risiko korban menurut Separovic, ${ }^{24}$ salah satunya faktor pribadi, di sini termasuk faktor biologis (usia, jenis kelamin, kesehatan, terutama kesehatan jiwa). Hentig membagi tipe korban menjadi 13 (tiga belas) macam, salah satunya adalah "The Old", bahwa orang tua mempunyai risiko menjadi korban atas tindak pidana terhadap harta kekayaan. Di sisi lain terdapat kelemahan, pada jasmaninya atau terkadang mentalnya yang mulai lemah. ${ }^{25}$ Termasuk pula salah satu tipologi dari Steven Schafer adalah "Biologically weak victims", yakni siapa saja yang secara fisik atau mental lemah, misalnya orang yang sangat muda atau sangat tua dan orang yang tidak sadar menjadi targer kejahatan. ${ }^{26}$

Berkaitan dengan hal di atas, 3 (tiga) kasus dari 10 (sepuluh) kasus kejahatan begal menunjukkan umur korban antara lain 54 (lima puluh empat) tahun, 52 (lima puluh dua) tahun, dan 72 (tujuh pulah dua) tahun. Sekalipun dua korban tersebut bukan usia yang sangat tua (54 dan 52 tahun), namun pada usia tersebut dapat terjadi

24 Angkasa dan Iswanto, Op.Cit, hlm. 30. Ibid,hlm. 31.

Yazid Efendi,Op.Cit, hlm.29. 
penurunan ketahanan fisik dan mental. Oleh karenanya korban di sini lebih dapat dilumpuhkan pelaku kejahatan begal yang berusia lebih muda, sehingga menjadi target yang menarik bagi pelaku.

Salah satu tipe korban menurut Hans Von Hentig adalah "The Female", yakni wanita merupakan korban dengan bentuk kelemahan lain, bahwa di samping lemah jasmaninya (apabila dibandingkan dengan pria dan pelakunya biasanya juga pria) wanita juga diasumsikan mempunyai dan/atau memakai barang-barang seperti perhiasan yang mempunyai nilai ekonomis tinggi. ${ }^{27}$ Berkaitan hal dengan kasus kejahatan begal, terdapat 5 (lima) korban dengan jenis kelamin perempuan dan 8 (delapan) korban dengan jenis kelamin laki-laki. Sekalipun korban dengan jenis kelamin laki-laki lebih banyak, namun perempuan memiliki risiko yang lebih tinggi untuk dapat dilumpuhkan pelaku berkaitan dengan kelemahan fisik dalam melakukan perlawanan.

Adapun berkaitan dengan sumber daya manusia yang kurang, dalam hal ini membawa pada akibat kekurang hati-hatian korban. Sedangkan perasaan takut terlebih dahulu atau mudah takut saat digertak atau diancam, dapat mempengaruhi terjadinya viktimisasi. Hal ini berkaitan dengan psikologis korban, di mana korban yang mudah merasa takut dan kemudian berhadapan dengan situasi yang membahayakan, tentunya mengakibatkan perlawanan korban lemah dan semakin mempercepat atau mempermudah pelaku melakukan kejahatan begal.

Angkasa dan Iswanto, Op.Cit, hlm. 31. lbid, hlm. 30.
Ketiga, faktor situasi, yakni korban berada di tempat yang memungkinkan terjadinya kejahatan begal,korban berada dalam situasi dan kondisi yang tidak memungkinkan melakukan perlawanan, sehingga mempengaruhi psikologisnya (rasa takut). Sebagaimana dikemukakan Separovic, ${ }^{28}$ bahwa salah satu faktor risiko korban adalah faktor situasi, yaitu keadaan konflik, tempat dan waktu.

Berkaitan dengan hal di atas, pada dasarnya bahwa situasi tempat mempengaruhi terjadinya viktimisasi kejahatan begal, di mana korban berada pada situasi yang sulit untuk melakukan perlawanan. Adapun menurut Hans Von Hentig, salah satu tipe korban adalah The blocked, exempted, and fighting. Orang yang terhalang, bebas, dan suka berkelahi memunyai risiko yang berbeda untuk terjadinya viktimisasi. Orang yang terhalang diartikan sebagai individu yang berada dalam posisi dan kondisi sulit untuk keluar dari bahaya. Mereka yang termasuk dalam tipe ini adalah orang yang terperangkap dalam situasi yang tidak memungkinkan untuk melakukan pembelaan atau bahkan tindakan tersebut justru menimbulkan penderitaan yang lebih serius. ${ }^{29}$

Berdasarkan hal di atas, hampir seluruh korban kejahatan begal tipe "the blocked". Hal ini dikarenakan korban dalam posisi dan kondisi yang sulit keluar dari bahaya, di mana korban mengalami kekerasan dan/atau dibawah ancaman pelaku begal. Situasi ini tentunya akan mempengaruhi psikologis korban, yakni menurunnya kekuatan mental korban, sehingga korban memilih untuk tidak melakukan perlawanan

29 Ibid, hlm. 34. 
ataupun perlawanan korban tidak dapat dilakukan secara maksimal. Merujuk hal tersebut, terlihat adanya perbedaan dengan korban yang memilki karakter perasaan takut terlebih dahulu atau mudah takut saat digertak. Dalam hal ini korban sejak awal kurang memiliki ketahanan mental atau psikis yang kuat, sehingga situasi berupa ancaman semakin mempercepat dan mempermudah pelaku melakukan kejahatan begal. Adapun pada tipe "the blod", korban di sini dari awal dapat memiliki mental yang kuat maupun yang lemah. Pada mental yang kuat, situasi berupa ancaman merupakan alat yang melemahkan mental atau psikis korban, sehingga korban sulit untuk melakukan perlawanan.

\section{Penanggulangan Kejahatan Begal di Polres}

\section{Banyumas}

Kebijakan kriminal atau penanggulangan kejahatan pada hakikatnya merupakan bagian integral dari upaya social defence dan upaya mencapai social welfare. Oleh karena itu, tujuan akhir atau tujuan utama dari kebijakan kriminal adalah perlindungan masyarakat untuk mencapai kesejahteraan masyarakat. ${ }^{30}$ Adapun guna memberikan perlindungan terhadap masyarakat berkaitan dengan kejahatan begal, salah satunya dapat melalui tugas dan fungsi Polisi Republik Indonesia (Polri).

Berdasarkan Pasal 13 Undang-Undang Nomor 2 Tahun 2002 tentang Kepolisian Negara Republik Indonesia (Undang-Undang Kepolisian),

30 Iza Fadri, "Kebijakan Kriminal Penanggulangan Tindak Pidana Ekonomi di Indonesia", Jurnal Hukum, Vol. 17 No.3, Juli 2010, Yogyakarta: FH UII, hIm. 445.

31 H. Pudi Rahardi, 2007. Hukum Kepolisian (Profesionalisme dan Reformasi POLRI), Laksbang Mediatama, Surabaya, hlm. 68. bahwa tugas pokok Kepolisian Negara Republik Indonesia adalah: (1) memelihara keamanan dan ketertiban masyarakat; (2) menegakkan hukum; dan (3) memberikan perlindungan, pengayoman, dan pelayanan kepada masyarakat. ${ }^{31}$ Adapun tugas selebihnya diatur dalam Pasal 14 UU Kepolisian.

Berkaitan dengan tugas dan fungsi preemtif Polri, menurut Awaloeddin Jamin bahwa dalam praktek di lapangan, Polri menyebut istilah preemtif ini sebagai "pembinaan masyarakat" atau "preventif tidak langsung", yaitu pembinaan yang bertujuan agar masyarakat menjadi law abiding citizens. ${ }^{32}$ Tugas atau fungsi preventif dibagi dalam dua kelompok besar: (a) Pencegahan yang bersifat fisik dengan melakukan empat kegiatan pokok, antara lain mengatur, menjaga, mengawal dan patroli; (b) Pencegahan yang bersifat pembinaan dengan melakukan kegiatan penyuluhan, bimbingan, arahan, sambung, anjang sana untuk mewujudkan masyarakat yang sadar dan taat hukum serta memiliki daya cegah-tangkal atas kejahatan. ${ }^{33}$ Pada poin ke dua ini sesungguhnya apa yang disebut sebagai tindakan preemtif atau preventiv tidak langsung. Tugas dan fungsi represif atau pengendalian, yang berarti bahwa Polisi itu berkewajiban menyidik perkaraperkara tindak pidana, menangkap pelakupelakunya dan menyerahkan kepada penyidikan (yustisi) untuk penghukuman. ${ }^{34}$

Berdasarkan hasil penelitian menunjukkan upaya penanggulangan kejahatan begal yang telah

32 Paul Ricardo, Op.Cit.

33 Ibid

34 M. Faal, 1991. Penyaringan Perkara Pidana Oleh Polisi (Diskresi Polisi), Pradnya Paramita, Jakarta, hlm. 43. 
dilakukan Polres Banyumas, termasuk pula Polsek jajaran Polres Banyumas dapat dilihat dalam tabel di bawah ini:

Tabel 1. Penanggulang Kejahatan Begal di Polres Banyumas dan Polsek Jajaran Polres Banyumas

\section{Preemtif:}

1. Sosialisasi dari fungsi Bimas (Bimbingan dan Penyuluhan Masyarakat), Sabara, maupun polsek-polsek berkaitan dengan kejahatan begal;

2. Program mengabdi dan melayani yaitu dengan safari KAMTIBMAS (Keamanan Ketertiban Masyarakat) kepada tokoh masyarakat maupun perangkat desa;

3. Pembinaan masyarakat melalui Polmas (mengaktifkan Polmas);

4. Menggandeng media massa agar menyampaikan kepada masyarakat untuk selalu waspada dengan kejahatan begal.

\section{Preventif}

1. Strong point di daerah rawan baik dari Polres maupun Polsek;

2. Melaksanakan operasi rutin;

3. Pendekatan dan Penyebaran Informan;

4. Pendekatan terhadap residivis.

Represif
1. Menangkap pelaku dan
memprosesnya sesuai dengan
prosedur hukum yang berlaku;
2. Pembinaan secara langsung saat
penyidikan secara personal
terhadap pelaku;
3. Memberantas penadah;
4. Sikap tegas terhadap pelaku, yakni
jika meresahkan masyarakat dan
melawan petugas dilakukan tembak
ditempat sesuai dengan SOP.

Merujuk hal di atas, terdapat upaya penanggulangan kejahatan begal yang cukup komprehensif yang telah dilaksanakan Polres Banyumas dan jajarannya sebagai pelaksana hukum, yakni terdiri dari upaya preemtif, preventif, dan represif. Adapun demikian berdasarkan hasil penelitian pula masih terdapat faktor-faktor penghambat dalam penanggulangan kejahatan begal, antara lain: (1) Wilayah luas; (2) Pelaku lintas daerah; (3) Korban tidak melapor atau kurang cepat melapor; (4) Masyarakat kurang responsive dan kooperatif dalam memberikan keterangan, tidak memberikan keterangan seutuhnya dan takut dijadikan saksi; (5) Kurangnya sarana IT; (6) Personil di Polsek kurang; (7) Instansi lain kurang kooperatif.

Hal di atas, tentunya membawa pengaruh sebagaimana dapat di lihat bahwa jumlah kasus kejahatan begal baik yang terjadi pada tahun 2014 dan 2015 adalah sama yakni masing 5 (lima) kasus, bahkan pada tahun 2014 terdapat 1 (satu) kasus belum terungkap dan tahun 2015 terdapat 2 (dua) kasus yang belum terungkap hingga sampai saat ini.

Merujuk pendapat Barda Nawawi Arief, bahwa terdapat beberapa faktor yang mempengaruhi dan menentukan kualitas penegakan hukum itu sendiri, yaitu:

1) kualitas individual (SDM);

2) kualitas institusional/struktur hukum (termasuk mekanisme tata kerja dan manajemen)

3) kualitas sarana/prasarana;

4) kualitas perundang-undangan (substansi hukum); dan 
5) kualitas kondisi lingkungan (sistem sosial, ekonomi, politik, budaya; termasuk budaya hukum masyarakat). ${ }^{35}$

Kualitas individual anggota Polri sangat menentukan penanggulangan kejahatan begal. Terdapat suatu korelasi bahwa, jika anggota Polri Polres Banyumas maupun jajarannya (Polsek) memiliki kualitas yang baik, maka ia dapat bekerja secara efektif dalam menghadapi hambatan teknis dilapangan. Hal ini senada dengan pendapat anggota Polri Polres Banyumas, ${ }^{36}$ bahwa berkaitan dengan penanggulangan kejahatan begal yang tepat bahwa yang terpenting adalah kemauan dan efektivitas anggota Polri dalam bekerja, sehingga jumlah anggota Polri bukan faktor utama.

Kualitas institusional/struktur hukum (termasuk mekanisme tata kerja dan manajemen). Masih kurangnya penanggulangan kejahatan begal yang berorientasi pada pelaku dan korban, maupun penanggulangan secara terpadu. Sebagaimana diketahui bahwa sekalipun penanggulangan kejahatan begal yang telah dilakukan cukup komprehensif yang terdiri dari aspek preemtif, preventif dan represif, namun demikian hal ini masih belum efektif, di mana salah satu faktor penghambat yang masih kerap terjadi adalah korban tidak melapor atau kurang cepat melapor dan masyarakat kurang responsif dan kooperatif dalam memberikan keterangan, tidak memberikan keterangan seutuhnya serta takut dijadikan saksi. Berdasarkan hal tersebut, menunjukkaan bahwa masih kurangnya rasa kepercayaan masyarakat terhadap Polri dan

35 Barda Nawawi Arief, 2008, Masalah Penegakan Hukum dan Kebijakan Hukum Pidana dalam Penanggulangan Kejahatan, Cetakan Kedua, Jakarta: Kencana Prenada Media Group, hlm. 20. kesadaran hukum masyarakat. Oleh karenanya upaya pencegahan penanggulangan secara preemtif dan preventive seharusnya lebih dapat dimaksimalkan, khususnya dilakukannya sosialisasi secara masif dan kontinyu kepada masyarakat mengenai kewaspadaan terhadap kejahatan begal dan upaya pencegahannya.

Termasuk pula adanya indikasi peniruan kejahatan begal dari wilayah lain, hal ini justru menunjukkan kurangnya kesiapan tugas dan fungsi Polri baik secara preemtif maupun preventif. Berkiatan dengan instansi lain yang kurang kooperatif, menunjukkan masih kurangnya kinerja secara terpadu dengan instansi lain. Sebagaimana menurut Muladi bahwa makna "integradted criminal justice system" adalah sinkronisasi atau keserempakan dan keselarasan, salah satunya adalah sinkronisasi struktural (structural synchronization) adalah keserempakan dan keselarasan dalam kerangka hubungan antara lembaga penegak hukum. ${ }^{37}$ Berdasarkan hal tersebut, perlu adanya kerjasa sama yang erat dengan Lembaga Pemasyarakatan (Lapas) guna mencegah timbulnya residivis kejahatan begal, kerjasama dengan polisi di wilayah lain dalam hal pemberian informasi, persamaan persepsi dan dukungan dari pihak kejaksaan maupun pengadilan berkaitan dengan sanksi pidana yang tepat bagi pelakut. Baik Kejaksaan, Pengadilan, Polisi wilayah lain, maupun Lapas dalam hal ini juga merupakan lembaga pelaksana hukum. Adapun di sisi lain, perlu adanya kerjasama sama yang erat dengan instansi yang bukan penegak

36 Wawancara dengan KBO Reskrim Polres Banyumas, tanggal 12 Mei 2015

37 Muladi, 1994, Sistem Peradilan Pidana Indonesia, Jakarta: Citabaru, hlm. 30. 
hukum, yakni Pemerintah Daerah (Pemda). Khususnya partisipasinya dalam sosialisasi pencegahan kejahatan begal, pengaktifan pos kampling, penambahan penerangan di wilayah yang rawan, menurunkan pengangguran dan meningkatkan kesejahterahan masyarakat guna menekan potensi calon pelaku kejahatan begal.

Kualitas sarana/prasarana. Sarana dan prasana merupakan faktor penunjang dalam melaksanakan penanggulangan kejahatan begal di Polres Banyumas. Terdapat suatu korelasi bahwa, kurangnya sarana IT, tentunnya akan menghambat ruang gerak anggota Polri terutama dalam mengahadapi wilayah Kabupaten Banyumas yang luas.

Kualitas perundang-undangan (substansi hukum).Sekalipun dalam UU Kepolisian tersirat adanya unsur tugas dan fungsi Polri secara preemtif, preventif dan represif, namun demikian perlu adanya penegasan substansi mengenai pembagian fungsi dan tugas tersebut. Penegasan secara umum perlu diadakan, mengingat selama ini pengelompokan tugas dan fungsi tersebut hanya diatur dalam doktrin dan tidak semua masyarakat dapat mengkualifikasikan sesuatu yang tersirat dalam undang-undang.

Kualitas kondisi lingkungan (sistem sosial, ekonomi, politik, budaya; termasuk budaya hukum masyarakat). Kualitas kondisi lingkungan menjadi masalah utama, di mana lingkungan sosial dan aspek ekonomi menjadi faktor kriminogen pelaku melakukan kejahatan begal. Termasuk pula sistem sosial mempengaruhi seseorang berisiko menjadi korban, di mana salah satunya adalah korban kejahatan begal dikarenakan mengenakan perhiasan yang berlebih dan adanya sikap para korban yang kurang waspada atau hati-hati dengan orang lain (terbuka pada orang lain).

Bilamana dikaitkan dengan terori Robert. B. Seidman, faktor-faktor yang cenderung berpengaruh terhadap tindakan penanggulangan kejahatan begal di Polres Banyumas sebagaimana dikemukakan di atas, dianalisis berdasarkan ke dalam faktor personal dan sosial lainnya, maka secara personal meliputi: (1) Motivasi pemimpin (Kapolres Banyumas dan Kapolda Jateng); (2) Dukungan dari instansi lain; (3) Jumlah personil dan sarana prasarana IT; (4) Efektivitas Kinerja (semangat personal, kepatuhan dan inovasi).

Adapun dianalisis berdasarkan ke dalam faktor sosial lainnya adalah sebagai berikut: (1) Perspketif dan sikap (respon) masyarakat yang telah membudaya dalam terjadinya kejahatan begal; (2) Respon korban dalam upaya penanggulangan kejahatan begal; (3) Lingkungan sosial pelaku; (4) Frekuensi sosialisasi penanggulangan kejahatan begal; (5) Kontrol sosial oleh Media massa, (6) Pengaruh ancaman sanksi pidana.

\section{PENUTUP}

\section{Simpulan}

Faktor-faktor yang mempengaruhi terjadinya kejahatan begal di Polres Banyumas dalam perspektif kriminologi adalah fakor ekonomi, lingkungan sosial pelaku, tempat kejadian perkara yang memungkinkan, peniruan kejahatan begal di wilayah lain (termasuk peran media), dan masih adanya penadah. Adapun dalam perspektif viktimologi adalah faktor perilaku korban, kelemahan biologis dan psikologis korban, dan situasi. 
Penanggulangan kejahatan begal yang telah dilakukan di Polres Banyumas cukup komprehensif yakni penanggulangan secara preemtif, preventif dan repersif. Namun demkian, masih belum efektif di mana terdapat beberapa hambatan dalam pelaksanaannya, antara lain wilayah luas, pelaku lintas daerah, korban tidak melapor atau kurang cepat melapor, masyarakat kurang responsif dan kooperatif dalam memberikan keterangan, tidak memberikan keterangan seutuhnya dan takut dijadikan saksi, kurang sarana IT, personil di Polsek kurang; instansi lain kurang kooperatif.

\section{Saran}

Pertama, tindakan preemtif yaitu dengan meningkatkan kuantitas dan kualitas sosialisasi kepada masyarakat dengan melibatkan Pemda Banyumas, melakukan kontrol sosial kepada media massa, meningkatkan kuantitas dan kualitas pembinaan Polisi Masyarakat.

Kedua, tindakan Preventif yaitu melaksanakan Strong point dan operasi di daerah rawan secara kontinyu, penambahan Informasi Teknologi, penambahan personil di Polsek, dan memonitor setelah ia keluar, pendekatan kepada Informan dan residivis secara personal dan kontinyu, membangun sinergitas dengan Polisi wilayah lain, Kejaksaan, Pengadilan, Lembaga Pemasyarakatan dan Pemerintah Daerah.

Ketiga, tindakan represif yaitu Pimpinan (Kapolres dan Kapolsek) memberikan motivasi kepada anggotanya untuk mengusut secara tuntas kasus kejahatan begal yang belum terungkap, melakukan pendekatan secara personal terhadap saksi agar dapat memberikan keterangan secara kooperatif, melaksanakan pembinaan secara informal dan kontinyu kepada pelaku pada saat penyidikan, memberantas penadah. Adapun di sisi lain, perlu adanya pengaturan mengenai tugas dan fungsi Polri secara preemtif, preventif, dan represif dalam bentuk Peraturan Kapolri.

\section{DAFTAR PUSTAKA}

Angkasa dan Iswanto. 2009. Viktimologi. Buku Ajar. Purwokerto: FH Unsoed;

Arief, Barda Nawawi. 2008. Masalah Penegakan Hukum dan Kebijakan Hukum Pidana dalam Penanggulangan Kejahatan. Cetakan Kedua. Jakarta: Kencana Prenada Media Group;

Ashshofa, Burhan. 2007. Metode Penelitian Hukum. Jakarta: Rineka Cipta;

Ediwarman. "Paradoks Penegakan Hukum Pidana Dalam Perspektif Kriminologi di Indonesia". Jurnal Kriminologi Indonesia. Vol. 8 No. 1. Mei 2012, Depok: Fisip UI, hlm. 41.

Efendi, Yazid. 2001. Pengantar Viktimologi: Rekonsialiasi Korban dan Pelaku Kejahatan. Purwokerto:Universitas Jenderal Soedirman;

Faal, M. 1991. Penyaringan Perkara Pidana Oleh Polisi (Diskresi Polisı). Jakarta: Pradnya Paramita;

Fadri, Iza. "Kebijakan Kriminal Penanggulangan Tindak Pidana Ekonomi di Indonesia". Jurnal Hukum. Vol. 17 No.3. Juli 2010, Yogyakarta: FH UII, hlm. 445.

Faesal, Sanapiah. 1990. Penelitian Kualitatif, Dasar-dasar dan Aplikasinya. Malang: Yayasan Asih Asah Asuh (Y A3);

Muladi. 1994. Sistem Peradilan Pidana Indonesia. Jakarta: Cita Baru;

Rahardi, H. Pudi. 2007. Hukum Kepolisian (Profesionalisme dan Reformasi POLRI). Surabaya: Laksbang Mediatama;

Ricardo, Paul. Upaya Penanggulangan Penyalaahgunaan Narkoba Oleh Kepolisian (Studi Kasus Satuan Narkoba Polres Metro 
Bekasi)". Jurnal Kriminologi Indonesia. Vol. 6 No.3. Desember 2010, Depok: Fisip UI, hlm. 237

Sumitro, Ronny Hanitijo. 1998. Metodologi Penelitian Hukum dan Jurimerri.Jakarta: Ghali Indonesia;

Susanto, I. S. 2011. Kriminologi. Yogyakarta: Genda Publishing;

Soekanto, Soerjono. 1982. Kesadaran Hukum dan Kepatuhan Hukum. Jakarta: Cv. Rajawali;

Waluyo, Bambang. 2011. Viktimologi (Perlindungan Saksi dan Korban). Jakarta: Sinar Grafika. 